\title{
Transnational Ties and Mental Health of Caribbean Immigrants
}

\author{
Eleanor J. Murphy ${ }^{1,3}$ and Ramaswami Mahalingam ${ }^{2}$
}

\begin{abstract}
Immigration scholars have demonstrated the increasing importance of transnational activities among contemporary immigrants. While much of the previous research has emphasized social and economic outcomes, very little attention has been paid to psychological well-being or mental health. Using a community sample of West Indian immigrants, we developed an empirical measure of the nature and frequency of transnational practices. The resulting Transnationalism Scale is examined for psychometric properties using an exploratory principal components factor analysis, and bivariate correlations with pre-existing measures of psychological well-being, perceived social support, and ethnic identity. Results reveal five factors, some of which are significantly correlated with measures of psychological well-being, social support, and ethnic identity. Findings suggest that transnationalism, as a construct, is a valid measure for this population. We argue that transnational ties shape various aspects of immigrants' lives.
\end{abstract}

KEY WORDS: immigrant; transnationalism; mental health; West Indians; scale; social support.

In studying immigrants' social adjustment, social scientists have focused on assimilation patterns and factors that may enhance or hinder assimilation in a particular immigrant group (1). A common definition of assimilation is the gradual incorporation into the new society via the adaptation of the customs and values of that society with a simultaneous relinquishment of traditional customs and values of the sending society. This construct has also been utilized by many analysts in developing frameworks for understanding immigrants' patterns of general settlement, their modes of incorporation into the host society, and the social, economic, political, and psychological outcomes for these immigrants (1-5). More recently, however, researchers have noted that the assimila-

\footnotetext{
${ }^{1}$ Department of Epidemiology, Mailman School of Public Health, Columbia University, New York, New York.

${ }^{2}$ Department of Psychology, University of Michigan, Ann Arbor, Michigan.

${ }^{3}$ Correspondence should be directed to Eleanor J. Murphy, Department of Epidemiology, Mailman School of Public Health, Columbia University, 722 West 168th Street, New York, New York 10032; e-mail: em713@columbia.edu.
}

tionist model is significantly limited in view of the fact that current immigration and settlement patterns are deviating from the traditional ways in which previous immigrant groups might have been incorporated in the United States $(6,7)$. While assimilation may have been conceptualized as a linear process at one time, within the last decade or so, many researchers have begun to address the notion of a more complex and globalized form of immigrant adaptation and integration. For example, many recent immigrants have been observed to retain extensive ties to their home countries while attempting to settle and develop in the new country (8). Consequently, a variety of constructs are now emerging and these relatively newer expressions have been broadened to accommodate the contemporary forms of migration and settlement.

A highly salient concept that has emanated from this discourse is transnationalism or transnational ties (9-13). Among the major transnational theorists, Portes and colleagues have defined transnationalism as the maintenance of occupations or activities that necessarily require regular social contacts 
over time across national borders and/or across cultures (12). Foroun and Glick Schiller (14) advanced the concept of transnationalism as a constant movement developed and sustained by immigrants who build extensive networks linking the new country and the country of origin. At a glance, these definitions convey the idea that transnationalism occurs on a variety of levels, from familial and cultural to economic and political. Instances of transnationalism can be found with the Salvadorians living in New York, who send remittances and write letters to friends and family back home (15); the Dominicans who establish political parties with offices that span the United States and the Dominican Republic (16); the West Indians who feature the largest annual ethnic and cultural parade in New York $(2,3)$; the Asian-Indians who promote investments in business ventures in India (17), and so forth. Indeed, research analysts have begun to develop theoretical and empirical bodies of literature that take into account these forms of interactions. While transnational practices have always occurred, even among the earliest waves of immigrants, recent technological advances (both in the home countries and in America) have made the study of this topic more accessible than before $(2,3)$. For example, prepaid phone cards along with decreasing rates have allowed immigrants to indulge in more frequent and longer contact with loved ones via telephone. Rapid transformations in the media like television, videotapes, and, most recently, the Internet have exponentially broadened the range and intensity of transnational ties. Consequently, virtually every recent immigrant group features many different forms and levels of transnationalism.

From previous works on various immigrant populations, it is obvious that transnational ties play an increasingly bigger role in the lives of immigrants. Researchers have pondered the relative importance of focusing on transnationalism as a dominant force, and in doing so they have also noted the complexities and ambiguities associated with this concept, and are continually attempting to refine and clarify the process of transnationalism. Certainly, several questions surrounding this phenomenon remain to be addressed. For example, what might be some between-group and within-group differences in transnationalism? Can certain transnational activities be categorized based on some common thread, such as frequency, modes of access, or the characteristics of the people using them? What role, if any, do transnational ties play among children of immigrants who are born in the United States? In keeping with some of these attempts, the study described in this article utilizes an empirical approach to quantifying transnational practices, by developing preliminary scale and examining some of its psychometric properties. In addition, social and psychological outcomes are correlated with this measure to further validate the transnationalism construct. A significant body of literature based on ethnographic research has already provided foundations for developing empirical constructs. This study employs some of these descriptions and endeavors to reify them into a quantifiable measure of transnational ties.

At this juncture, it would be useful to discuss various forms of transnational practices, hence providing a foundation for the items on the Transnationalism Scale. An important caveat is that some of the activities are not immediately apparent as transnational activities, since they may seem routine and common to immigrants and nonimmigrants alike. However, even the same activity may present completely different interpretations depending on whether the individual doing the activity is an immigrant or not. For example, a third or fourth generation Mexican-American who visits Mexico might view the visit as a more symbolic activity, whereas for a first generation Mexican, this activity may have a direct impact on his or her current life circumstances.

\section{THE NATURE OF CURRENT TRANSNATIONAL PRACTICES}

One of the basic ways in which immigrants maintain ties with their home countries is through contact with relatives and/or friends whom they have left behind $(2,3)$. This type of contact usually involves communication and the provision of money and goods by the immigrant to the people left at home. For instance, in West Indian families, a pattern of immigration called serial migration occurs usually when the head of a household, usually a mother or father, leave the Caribbean to seek employment in the United States. Occasionally the family may migrate as one unit, but in the majority of families, at least some of the children are left behind to continue schooling, while the parent gets established in the new country. This phenomenon necessitates continuous contact between the parent and the children across borders, or between the parent and the person(s) left in 
charge of the children. Thus parents may continue to provide financial support by sending remittances, or by sending material goods to those left behind $(2,3,18)$. In addition, relatives may communicate with each other via telephone, airmail, e-mail, and so forth. Sending remittances and communicating via letters have been shown to be common transnational activities of Salvadorian immigrants in suburban New York (15).

Another way of achieving contact is by traveling back to the home country to visit friends and relatives, or providing assistance for friends and relatives to visit. The frequency and nature of this may depend on several factors such as affordability of vacations, immigration status, and conditions in home country $(2,3,19)$. Because of the increasing availability of affordable airline tickets, traveling back and forth on a regular basis has become relatively easy even for the less affluent immigrants. The ease of travel in turn facilitates business and economic transactions between borders. The question remains whether traveling to visit should be classified as a transnational activity, since almost everyone who can afford to travels at some point in his or her life. Again, this might be somewhat difficult to tease apart, since only a subjective appraisal by the immigrant may dictate just what type of travel and visitation is taking place. Another form of transnational travel occurs when immigrants come to the United States seeking temporary employment, work in the United States for a few months, and then return home. This cyclical employment pattern may continue over a period of several years, until the immigrant may decide to stay permanently in the United States (20). Examples of such can be found with housekeepers, nurse's aides, and manual laborers.

For many immigrants who are unable to travel frequently, the presence of a vibrant cultural arena in the host country may ward off feelings of alienation and facilitate adjustment. Most immigrants tend to reside in niches or enclaves for that reason $(2,3$, 20). Among Caribbeans, for example, many of the cultural activities take place in the form of leisurely and informal get-togethers, parties, and social outings. Other activities such as club meetings, church services, and concerts may be more formally planned and attended. Cultural ties do not only maintain emotional affirmation, but may also lead to instrumental support through contact with other immigrants $(2,3)$.

Although some cultural activities may be pursued on a largely individual and informal basis, with the view that they are purely social and leisurely outlets, others may be seen as vehicles for further agency and developments and thus require more organized planning in the form of group solidarity and leadership. Some of these cultural practices may have further implications for economic and other social conditions in the lives of immigrants as well as those remaining in the home countries. Thus a broad array of political activism may emerge from what started as cultural pursuits.

Individuals who have achieved a certain degree of economic autonomy may use their economic success in the United States to generate and maintain further economic activity in their homelands $(2,3$, 17). Furthermore, they may start businesses in the United States that rely on the importing of commodities from their home countries. Because of the desire to continue traditional customs, immigrants create a local market for these goods and services that can be obtained from resources in their home countries. Conversely, there may be immigrants who send remittances and products from the United States back to their home countries to maintain grocery stores and other businesses there. Other immigrants may see opportunities for investment in real estate back home, while establishing the United States as their primary residence.

\section{Transnational Ties, Social Outcomes, and Mental Health}

The social implications of transnationalism at the community, familial, and individual levels have been recognized despite the relative ambiguousity around its definition $(21,22)$. Immigration literature has begun to focus on transnational ties and practices among new immigrants, with the recognition that they may serve to socially enhance the immigrants' lives by directly or indirectly promoting and maintaining valuable social networks. In fact current bodies of work stress the findings that transnational ties can produce desirable social and economic among immigrant groups, including West Indians (2, 3, 23, $24)$. Yet, transnationalism is rarely studied in mental health literature. However, social support, ethnic identity, and perceived discrimination, all of which are impacted by transnationalism, have been previously linked to psychological outcomes. To date, there are no studies that examine the ways in which the maintenance of transnational ties plays a role in mental health outcomes for Caribbean immigrants. 


\section{Transnational Ties and Social Support}

Transnationalism has been shown to solidify social networks among immigrants (23), which in turn have implications for psychological well being. This is because the social networks may produce tangible resources, social capital, and emotional support that may offset some of the alienating and stressful effects of immigration. A corpus of research devoted to investigating the impact of social support has resulted in a large number of empirical studies that provide evidence for the postulation that social support serves to directly decrease emotional distress, and also functions as a buffer against the stress brought about by trying events (25). Allen (26) maintained that most first-generation and even some second-generation West Indians tend to have a kind of "sojourner" status. Thus they keep in close contact with other West Indians by residing in ethnic enclaves (27), participating in social organizations such as sports, taking regular trips to the Caribbean, funding relatives, and sponsoring social and political events in the Caribbean (21).

Most bodies of social support literature tend to advance the general view that social support and social interactions are highly beneficial to psychological well being (28). Nonetheless, some studies have yielded mixed findings on this issue, and point to the paradoxical nature of such social activities that may serve to increase rather than decrease everyday stress (29). Some studies for instance have elucidated the fact that because of their migration patterns some Caribbean immigrants are obliged to operate transnationally (22). Under those conditions, transnational ties may not necessarily yield positive consequences. For example, children may remain in the Caribbean for schooling, while their parents are in the United States; women may travel back and forth to obtain temporary domestic work, and so forth (21). While these activities may help them to achieve social cohesion, by forcing them to retain contact with certain networks or people, it might also place a burden on those in the provider role. In addition, it can be speculated that a certain type of frustrating nostalgia may be induced via prolonged, but distance contact with loved ones. Besides relational burdens, it has been debated that relying on transnational connections might be a poor professional and economic strategy in the long run, keeping immigrants in low paying, low-status occupations and enhancing suspicion and mistrust of fellow immigrants (30). So it is reasonable to expect that transnational ties may promote a desirable social support network with this caveat in mind.

\section{Transnational Ties and Ethnic Identity}

Besides enhancing social cohesion and a sense of social support, transnational ties may also help immigrants to consolidate their ethnic identity at a time when they may find a number of different identities suddenly thrust upon them. Ethnic identity has been defined as a person's subjective sense of belonging to a certain group or culture (31). This construct has received a great deal of attention among social psychologists. Given the multiethnic society that America has become, largely because of immigration, it is apparent that ethnic identity has important implications for the way in which people see themselves and their perception of how society responds to them, both of which impact psychological well being (32). For Caribbean immigrants of African descent, ethnic identity comes into play for a number of reasons. Like their Europeandescended immigrant counterparts, West Indians arrive in the United States with the hope to integrate and assimilate into the larger society (5). However, unlike the former group, the latter group's ability to assimilate is restricted along racial lines (33), like other minority immigrants of color. If and when they do assimilate, their assimilation by and large is limited to the larger group of African Americans.

In the United States, African Americans have been among the most disparaged groups, even compared to other ethnic minority groups, having a historical legacy of slavery and oppression $(5,34)$. Caribbean immigrants are racially similar to African Americans and share certain historical elements of being forcibly removed from their homeland and brought to another country to work as slaves. However, immigrants from the Caribbean have been able to enjoy relative autonomy in their home countries due to the absence of the colonizers who initially enslaved them. There, Blacks are in the majority and the everyday racial persecution and harassment encountered by African Americans is largely absent in the Caribbean $(5,35)$. Hence, the immigrants enter the United States with an outlook similar to that of other immigrant groups-one that encourages them to believe that hard work, education, and determination can overcome all obstacles, including racism (6). Phinney and Onwughalu (34) conducted 
a study comparing the effects of racial identity on the attitudes toward American values, among African Americans and African immigrants. They found that for African Americans, a racial identity was strongly associated with a negative attitude toward American ideals, but positively correlated with selfesteem, whereas for the African immigrants, there was no correlation between racial identity, attitudes, and self-esteem.

It has been argued that West Indian immigrants have an identity which stresses their country of origin; and while they do have a Black racial identity, it is produces a different kind of consciousness than that of African Americans (24). Furthermore, immigrants with stronger transnational ties tend to have a stronger ethnic identity, which serves as a potential buffer against racial prejudice (24). This "identity" offers them psychological protection in a number of ways. Firstly, maintaining the idea that they came from a culture where they are valued and accepted, and secondly, that they have the option to go back there if things do not work out in the host country, and can be very comforting to immigrants who feel a sense of alienation (24). It has also been suggested that this immigrant identity may be tested and threatened as they spend more time in the United States and become more aware of the pervasive nature of racial discrimination $(24,34,36)$. This may lead to increased frustration and dissatisfaction with life.

As research suggests, ethnic identity may also influence the perception of and stress associated with racial discrimination (36). Afro-Caribbeans with an immigrant identity may understand that racism exists; they may not necessarily choose to focus on it as the most determinative factor in their lives. Instead the emphasis is placed on opportunities and rewards for ambition and hard work. Again, the ability to bypass racism as an explanation for poor treatment in society may decline as the immigrant spends more time in the United States $(5,23)$. Nonetheless it is expected that having a strong ethnic identity will be positively associated with psychological well being.

It can be seen that transnational practices are pervasive among contemporary immigrants, and are likely to increase tremendously over the next several decades. By developing a transnational measure, this study hopes to link bodies of literature from the social and behavioral sciences in order to capture the nature and utility of transnational ties in the lives of new immigrants.

\section{METHOD}

First generation West Indian immigrants $(N=$ 137) residing in urban New York were recruited to participate in this study. Potential participants were solicited via word of mouth, electronic mail, and fliers, and the surveys were given in a wide range of settings such as colleges, laundromats, and beauty salons. Permission was obtained from the City University of New York to recruit students through the introductory psychology subject pool requirement on one of their campuses. Students who completed the survey through the subject pool received one hour of subject pool credit. In addition, some participants opted to do a web-based version of the survey, through which they could submit their responses directly to the study database via a personal computer. Those who responded electronically were given a monetary compensation of $\$ 12$, while those who completed the pencil-and-paper version were given $\$ 10$.

\section{Participants}

Participants consisted of 50 males and 87 females. They ranged in age from 18 to $60(M=27.48$, $S D=9$ ). A total of 12 Caribbean countries of origin were reported and the age of migration ranged from 10 to 45 , with the mean of 19.4 years. The immigrants reported living in the United States for an average of 7.7 years. Seventy-one percent of the respondents were single, $19.7 \%$ were married, while $8 \%$ were divorced or widowed. About $2 \%$ did not complete high school; $29 \%$ had a high school diploma or equivalent; $52 \%$ had some college courses, with $10 \%$ earning a college degree, and $3 \%$ earning a professional or graduate degree. The annual household incomes reported ranged from less than $\$ 10,000$ to $\$ 80,000$ or higher, with the median income range being $\$ 30,000$ 39,999 .

\section{Measures}

\section{Transnationalism Scale}

Twenty-one items were developed for the Transnationalism Scale. These items were developed by drawing upon previous qualitative research that described the nature and extent of transnational activities among various immigrant populations including West Indians. The items were grouped into four 
domains (family ties, cultural ties, economic ties, and political ties) for face validity. Each item described an activity and the respondents were required to indicate on a 6-point Likert scale $(0=$ have not done to $5=$ very often), the extent to which they participated in the activity within the past 2 years. A sample item is "Buy or import supplies regularly from the Caribbean." Individual scores for this measure were computed by taking an average (mean) of the scores for each item. Mean scores on this measure could range from 0 to 5 . A reliability coefficient as measured by Cronbach's $\alpha$ of 0.87 was generated for this sample.

\section{Social Support}

Social support was measured using the Multidimensional Scale of perceived social support (MSPSS) (37). This self-report measure consists of 12 items designed to assess a subjective evaluation of social support from family, friends, and significant other. Participants are required to indicate the extent to which they agree or disagree with the items that are measured on a 7-point Likert scale $(1=$ strongly agree to $7=$ strongly disagree). An example of an item is "I can count on my friends when things go wrong." The MSPSS has been used in a wide variety of populations, settings, and on normal and psychiatric populations. Additionally, the scale has been found to yield high internal consistencies across samples, and is negatively correlated with depression and anxiety. A Cronbach's $\alpha$ of 0.90 was obtained for this measure.

\section{Ethnic Identity}

Eleven items from the Multi-Ethnic Identity Measure (31) were used to assess the extent to which an individual harbored positive feelings about and regularly engaged in activities common to his or her ethnic group. This measure has been extensively used and validated among a wide range of ethnic groups. Responses were scored on a 4-point Likert scale $(4=$ strongly agree to $1=$ strongly disagree $)$. Two of the items were reversed scored. An example of an item on this measure is "I am active in social groups and organizations that include mostly members of my own ethnic group." A Cronbach's $\alpha$ of 0.69 on this measure was generated for this sample.

\section{Stress}

An index of an individual's subjective experience of stress was measured through the Perceived Stress Scale (38), which was developed for use among community samples. The initial scale consisted of 14 items and was demonstrated to have adequate validity for the reference sample. In this study 10 of the items were used to assess the frequency of which an individual perceives himself or herself as being able to cope adequately with various situations over the past month. The responses are scored on a 5-point Likert scale $(1=$ not at all stressful to $5=$ very stressful), and four items were reverse scored. A sample item on this scale is "In the last month how often have you felt that you were unable to control the important things in your life?" The reliability coefficient obtained for this measure was 0.81 .

\section{Perceived Racism}

The Daily Life Experience (DLE) scale was used to assess episodes of perceived racism as they occur from day to day. The items for this measure were adapted from the brief version of the Racism and Life Experiences Scale (RaLES-B) (39). Seventeen items were used to assess the extent to which a particular event bothered the participant. The items were scored on a 5-point Likert scale $(1=$ doesn't bother me to $5=$ bothers me extremely). Respondents were to first read a statement describing the event, and then they were required to indicate how much it bothers them. If they believed that they had not experienced the event in the past year, they were to circle "0." A sample item on this measure includes "Being observed or followed while in public places." A reliability coefficient of 0.95 was obtained for this sample.

\section{Life Satisfaction}

The Satisfaction with Life Scale (SWLS) is a commonly used measure to assess global satisfaction with life. This scale has been utilized among diverse groups and has been shown to have good internal consistency and validity (40). The SWLS consists of five positively phrased statements, such as "The conditions of my life are excellent." Respondents are required to indicate the extent to which they agree or disagree with each statement by using points 1 (strongly agree) through 7 (strongly disagree). An 
alpha coefficient of 0.86 , and a split-half reliability of 0.75 were achieved for this sample.

\section{Depression}

The magnitude of depressive symptoms was measured through the Beck Depression Inventory (BDI). The inventory consists of 14 groups of statements derived from descriptions of symptoms among clinically depressed and normative samples (41). In each group, the statements are presented with corresponding numbers, from the least severe (0) to the most severe (3). Participants are required to choose the number corresponding to one of the four statements in the group that most describes them. An example of a group of statements would be (0) "I do not feel like a failure," (1) "I feel that I have failed more than the average person," (2) "as I look back on my life, all I can see is a lot of failures," (3) "I feel I am a complete failure as a person." Thirteen of the statements were used in this sample, and an $\alpha$ coefficient of 0.92 was generated, while the split-half reliability was 0.89 .

\section{Anxiety}

The Beck Anxiety Inventory (BAI) was used to measure the presence of anxiety among participants (42). This inventory comprises 21 phrases that describe symptoms of anxiety. Participants are required to indicate the degree to which they experienced any of the symptoms over the past several weeks using a Likert scale ranging from 0 (not at all) to 3 (severely). A sample items on the BAI are "wobbliness in the legs" and "fear of losing control." This measure has been extensively studied and validated, and used for its psychometric properties. A coefficient $\alpha$ of 0.93 was obtained, while the split-half reliability was 0.88 in this sample.

\section{RESULTS}

None of the respondents reported not participating in any transnational activity. The mean transnationalism score was $1.8(\mathrm{SD}=0.68)$. The lowest average score for this sample was 0.29 , while the highest average score was 4.30 , with $90 \%$ of the respondents scoring an average of 3.00 or less. Descriptive statistics for the Transnationalism scale and other measures are presented in Table I. The first six
Table I. Means, Standard Deviations and Correlations of the Transnationalism Scale With Measures of Psychological Well Being, Perceived Social Support, Ethnic Identity, Stress, and Perceived Racism

\begin{tabular}{lccc}
\hline \multicolumn{1}{c}{ Other measures } & $\begin{array}{c}\text { Transnationalism } \\
\text { Scale (TS) }\end{array}$ & Mean & SD \\
\hline $\begin{array}{l}\text { Perceived social support } \\
\quad \text { MSPSS) }\end{array}$ & $0.23^{* *}$ & 4.73 & 1.12 \\
Ethnic identity (MEIM) & 0.12 & 3.00 & 0.50 \\
Perceived stress (PSS) & -0.02 & 2.83 & 0.66 \\
Perceived racism (DLE) & -0.05 & 2.92 & 1.20 \\
Anxiety (BAI) & 0.13 & 0.67 & 0.59 \\
Depression (BDI) & $0.20^{*}$ & 0.53 & 0.61 \\
Life satisfaction (SWLS) & $0.20^{*}$ & 4.20 & 1.6 \\
\hline$* p<.05 ; * * x \leq .01$. & & &
\end{tabular}

items on the questionnaire that made up the "Family/ social ties" domain yielded an average score of 2.72 $(\mathrm{SD}=0.94)$. The next five items that comprised the "Cultural ties" domain had an average score of 2.34 $(\mathrm{SD}=1.34)$. Following was the "Economic ties" domain, made up of five items with a mean score of 1.34 $(\mathrm{SD}=1.19)$. The last group of five items made up the "Political ties" domain and yielded an average score of $0.78(\mathrm{SD}=1.12)$.

Transnationalism $(r=0.23, p \leq 0.01)$ was positively and significantly correlated with perceived social support (see Table I). However, there were no systematic relationships between transnationalism, ethnic identity, stress, and perceived racism. Among the measures of psychological well being, transnationalism was significantly and positively correlated with life satisfaction $(r=0.20, p<0.05)$ and depression $(r=0.20, p<0.05)$, but unrelated to anxiety.

A principal components factor analysis was conducted in order to examine the underlying structure of the Transnationalism Scale. The initial extraction yielded six components that accounted for $66.6 \%$ of the cumulative variance of the scale. A varimax rotation revealed the presence of six distinct factors, five of which were analyzed for their psychometric properties (see Tables II and III). The factors were tentatively named based on the items that comprised them. One of the factors consisted of two items that appeared to be conceptually unrelated and was consequently dropped. Two items were omitted from the factors because they loaded on two or more items, and their factor loadings were below 0.50 . The five remaining factors were subsequently examined in more detail.

The first factor was called "Political and Economic Activism" and comprised two items from the 
Table II. Summary of Items and Factor Loadings for Varimax Orthogonal Six-Factor Solution for the Transnationalism Scale $(N=137)$

\begin{tabular}{|c|c|c|c|c|c|}
\hline \multirow[b]{2}{*}{ Item } & \multicolumn{5}{|c|}{ Factor loading } \\
\hline & 1 & 2 & 3 & 4 & 5 \\
\hline 19. Travel to/from Caribbean to do research on political conditions & 0.82 & & & & \\
\hline 13. Own Caribbean business(es) in the United States & 0.80 & & & & \\
\hline 12. Own business(es) in the Caribbean & 0.70 & & & & \\
\hline 21. Actively participating in Caribbean political organizations & 0.63 & & & & \\
\hline 18. Writing for a Caribbean newspaper or magazine & 0.62 & & & & \\
\hline 11. Sponsoring Caribbean entertainers to perform in the United States & $0.49^{a}$ & 0.42 & & & \\
\hline 10. Participate in Caribbean clubs at school, work or other venue & & 0.80 & & & \\
\hline 8. Participate in or attend games sponsored by Caribbean organizations & & 0.78 & & & \\
\hline 7. Participate in or attend Caribbean festivities & & 0.64 & & & \\
\hline 9. Attend church primarily attended by other Caribbean immigrants & & 0.58 & & & \\
\hline 16. Invest in property in the Caribbean & 0.37 & $0.38^{a}$ & & & \\
\hline 14. Buy or import supplies regularly from the Caribbean & & & 0.78 & & \\
\hline 1. Send money or supplies back home to relatives & & & 0.59 & & \\
\hline 17. Giving money to support political causes back home & 0.47 & & $0.53^{a}$ & & \\
\hline 20. Sponsoring charities back home & & & 0.46 & & \\
\hline 2. Travel back home to visit children, parents and other relatives & & & & 0.90 & \\
\hline 3. Travel back home to visit friends & & & & 0.88 & \\
\hline 5. Keep regular communication with relatives back home & & & & & 0.82 \\
\hline 6. Keep regular communication with friends back home & & & & & 0.77 \\
\hline
\end{tabular}

Note. $N=137$ and $\alpha=0.87$ for entire measure.

${ }^{a}$ The higher loading for items that load within 0.1 on another factor.

Table III. Principa-Components Analysis With Varimax Rotation and Coefficient Alphas for the Five Factors

\begin{tabular}{cc}
\hline Item & Factor loading \\
\hline Factor 1: Political and Economic Activism $(\alpha=0.86)$ \\
19. & 0.82 \\
13. & 0.80 \\
12. & 0.70 \\
21. & 0.63 \\
18. & 0.62 \\
Factor 2: Social and Cultural Ties $(\alpha=0.77)$ \\
10. & 0.80 \\
8. & 0.78 \\
7. & 0.64 \\
9. & 0.58 \\
Factor 3: Financial and Commercial Ties $(\alpha=0.68)$ \\
14. & 0.77 \\
1. & 0.59 \\
17. & 0.53 \\
20. & 0.46 \\
Factor 4: Social and Family-related Travel $(\alpha=0.86)$ \\
2. & 0.90 \\
3. & 0.88 \\
Factor 5: Social and Family-related Communication $(\alpha=0.73)$ \\
5. & 0.82 \\
6. & 0.76 \\
\hline
\end{tabular}

Note. $N=137$. Items numbered $4,11,15$, and 16 were omitted from the factors. original group of "Economic Ties" and three items from the original group of "Political Ties." A reliability coefficient as measured by Cronbach's $\alpha$ of 0.86 was generated for this domain. The second factor was called "Social and Cultural Ties." This factor consisted of four items all coming from the original group of "Cultural Ties." This domain had a reliability coefficient of 0.77 . The third factor was named "Financial and Commercial Ties" and consisted of four items, one coming from the original "Family and Social Ties" group, another coming from the original "Economic Ties" group and the last two coming from the original "Political Ties" group. A reliability coefficient of 0.68 was achieved for this factor. The fourth factor was named "Social and Family-related Travel" and consisted of two items from the original "Family and Social Ties" group and had a reliability coefficient of 0.86 . The fifth factor was named "Social and Family-related Communication" and consisted of two items from the original "Family and Social Ties" group. A reliability coefficient of 0.73 was generated for this factor.

Bivariate correlation analyses were conducted among the five factors (see Table IV). There was a significant negative correlation between the Economic/Political Activism and Social \& Familyrelated Communication, and a significant positive 
Table IV. Intercorrelations, Means, and Standard Deviations for the Six Factors of the Transnationalism Scale

\begin{tabular}{|c|c|c|c|c|c|c|c|}
\hline Factor & $\begin{array}{l}\text { 1. Political and } \\
\text { Economic Ties }\end{array}$ & $\begin{array}{l}\text { 2. Social and } \\
\text { Cultural Ties }\end{array}$ & $\begin{array}{l}\text { 3. Financial and } \\
\text { Commercial Ties }\end{array}$ & $\begin{array}{l}\text { 4. Social and Family- } \\
\text { related Travel }\end{array}$ & $\begin{array}{l}\text { 5. Social and Family- } \\
\text { related Communication }\end{array}$ & $M$ & $\mathrm{SD}$ \\
\hline 1. & - & $0.41^{* * *}$ & $0.57^{* * *}$ & $0.24^{* *}$ & $-0.27^{* *}$ & 0.68 & 1.1 \\
\hline 2. & - & - & $0.55^{* * *}$ & $0.34^{* * *}$ & 0.14 & 2.6 & 1.4 \\
\hline 3. & - & - & - & $0.38^{* * *}$ & 0.02 & 1.8 & 1.2 \\
\hline 4. & - & - & - & - & 0.08 & 2.2 & 1.6 \\
\hline 5. & - & - & - & - & - & 3.3 & 1.3 \\
\hline
\end{tabular}

${ }^{* *} p \leq 0.01 ;{ }^{* * *} p \leq 0.001$.

correlation between the Economic \& Political Activism and the other factors. Social and Cultural Ties was significantly and positively correlated with all the other factors except Social \& Family-related Communication. Similarly, Financial \& Commercial Ties, and Social \& Family-related Travel were all significantly and positively correlated with each other, but unrelated to Social \& Family-related Communication.

The factors were then correlated with the four outcome measures of perceived social support, ethnic identity, perceived stress, and perceived racism. At this point, the factors are referred to as subscales (see Table V). Perceived social support was positively and significantly related to Cultural \& Social Ties $(r=0.21, p<0.05)$, Financial and Commercial Ties $(r=0.21, p<0.05)$, and Social and Family-related Communication $(r=0.27, p<0.01)$, but showed no systematic relationships with Political \& Economic Activism and Social \& Family-related Travel. Ethnic identity was positively and significantly related to Social \& Family-related Communication $(r=0.29$, $p<0.001$ ), but unrelated to the other four subscales. Perceived stress was negatively and significantly related to Social \& Family-related Communication $(r=-0.21, p<0.05)$, but unrelated to the other four subscales. Perceived racism bore no systematic relationship to any of the subscales.

Finally, the associations between the three indices of psychological well-being and the five subscales (see Table VI) were explored. Political Ac- tivism was positively and significantly correlated with anxiety $(r=0.27, p<0.01)$ and depression $(r=0.37$, $p<0.001)$, but remained unrelated to life satisfaction. Social \& Family-related Communication was negatively correlated with anxiety $(r=-0.21, p<$ $0.05)$, while Social \& Family-related Travel was positively correlated with life satisfaction $(r=0.18$, $p<0.05)$.

\section{DISCUSSION}

In creating this measure, we are interested in exploring the underlying nature of transnational activities, the basic psychometric properties of the scale, and whether or not transnationalism is associated with certain social and psychological outcomes. The findings of this study indicate that transnationalism is multidimensional, spanning individual, familial, and broader social levels, and has important implications for social adaptation as well as psychological well being of West Indian immigrants.

The Transnationalism Scale as a whole demonstrated adequate reliability for this sample. While the average total score was lower than might be expected, it may simply reflect that some activities may be practiced relatively infrequently among this population. The exploratory factor analysis revealed five major factors of which showed a conceptual link between the items. Out of these factors, Social \& Family-related Communication yielded the highest

Table V. Correlations Between Transnational Subscales and Pre-existing Measures of Social Support, Ethnic Identity, Perceived Stress, and Perceived Racial Discrimination

\begin{tabular}{lrrrrr}
\hline \multicolumn{1}{c}{ Measure } & Subscale 1 & Subscale 2 & Subscale 3 & Subscale 4 & Subscale 5 \\
\hline Social support (MDSPSS) $\alpha=0.90$ & -0.04 & $0.21^{*}$ & $0.21^{*}$ & 0.17 & $0.27^{* *}$ \\
Ethnic identity (MEIM) $\alpha=0.69$ & -0.10 & 0.15 & 0.05 & 0.05 & $0.29^{* * *}$ \\
Perceived stress (PSS) $\alpha=0.81$ & 0.09 & -0.03 & 0.02 & -0.03 & $-0.20^{*}$ \\
Perceived racial discrimination (DLE) $\alpha=0.95$ & 0.03 & -0.08 & -0.05 & -0.08 & 0.01 \\
\hline
\end{tabular}

${ }^{*} p \leq 0.05 ;{ }^{* *} p \leq 0.01 ;{ }^{* * *} p \leq 0.001$. 
Table VI. Correlations Between Transnational Subscales and Pre-Existing Measures of Anxiety, Depression and Life Satisfaction

\begin{tabular}{lccccc}
\hline \multicolumn{1}{c}{ Measure } & Subscale 1 & Subscale 2 & Subscale 3 & Subscale 4 & Subscale 5 \\
\hline Anxiety (BAI) $\alpha=0.93$ & $0.27^{* *}$ & 0.06 & 0.11 & -0.00 & $-0.21^{*}$ \\
Depression (BDI) $\alpha=0.92$ & $0.37^{* * *}$ & 0.05 & 0.15 & 0.10 & -0.15 \\
Life satisfaction (SWLS) $\alpha=0.75$ & 0.12 & 0.17 & 0.13 & $0.18^{*}$ & -0.06 \\
\hline
\end{tabular}

${ }^{*} p \leq 0.05 ;{ }^{* *} p \leq 0.01 ;{ }^{* * *} p \leq 0.001$.

average score, followed by Social and Cultural Ties. Political and Economic Activism yielded the lowest average score. This result may be somewhat misleading, given that, on first glance it may seem that West Indians generally refrain from political activities. However, it has been posited that many West Indians engage in political and economic activism within social and cultural domains $(2,3,20)$.

While the original grouping of items reflected not only the activity being done, but also with whom that activity was being done, the newly extracted factors appear to center primarily on the activity that is done and not with whom it is being done. For example, "traveling back home to visit family" and "communicating regularly with family" were initially grouped together under "Family ties." After the factor analyses were conducted, they were separated under "Travel" and "Communication," respectively. This finding lends further support to the idea that the transnational activities themselves are specific and not just arising out of social relationships.

The correlational results appear to trump communication as an especially important transnational activity. Social \& Family-related Communication appears to stand by itself when compared with the other factors. It was significantly correlated with social support, ethnic identity, and perceived stress, while the other factors were either correlated only with social support, or none of the other social measures. The West Indian culture has been described as a "strongly oral culture" (20), with the idea that community members place great emphasis on communication as a means of socializing, obtaining, and giving out important information (43). What might be considered as idle gossip to others may in fact be seen as essential pieces of information in this population. Consequently, there may be instrumental as well as emotional benefits that ward off stress and promote a sense of belonging and support to people who frequently engage in this practice.

While transnationalism was positively associated with life satisfaction, it was also positively associated with depression, which is an unexpected result, given the negative relationship between depression and life satisfaction. However, it appears that people who engage in political activism are more likely to experience depression, and that result may explain the positive association between transnationalism and depression. Political and economic activism might be viewed as functional activities, which may not necessarily yield the emotional rewards that social communication does. Hence West Indians who are very active politically may be at risk of burnout and other factors that lead to depression. They may be also more aware of and less insulated from the harsher realities of overcoming cultural and economic barriers that plague many immigrant groups. As expected, Social \& Family-related Communication was negatively associated with Anxiety, consistent with the idea that this communication serves as an emotional buffer, while Social \& Family-related Travel was positively associated with Life Satisfaction. Social \& Family-related Travel may be contingent on a certain type of economic prosperity, which in turn may influence life satisfaction among these immigrants.

In interpreting the results of this study, it is important to be aware of some of its limitations. Much of the sample comes from participants under age 35, who have resided in the United States for less than 10 years. Additionally, the tendency to produce socially desirable responses is measurably increased with self-report measures. This may warrant the necessity to view some of the psychological outcome results with caution. However, the results of this study shed some important light on precise ways in which transnationalism impacts immigrants. Consequently, the limitations should not detract from the overall goal of further assessing and refining measures of transnational practices

The complex pattern of association between transnationalism and the social and psychological factors suggest that this phenomenon comprises important activities, some of which might be the result of current circumstances that immigrants find themselves in, others of which help to bring about 
and maintain improvements in the lives of West Indians. This scale is an early and important step in linking transnationalism with broader adaptation and integration strategies. While it remains to be seen whether such a scale can be fitted into a more generic template and used among other immigrant groups, the Transnational Scale has already demonstrated some reliability and validity for use among Englishspeaking Caribbean immigrants. It is necessary to conduct further research that would be instrumental in refining this measure, thereby increasing its overall utility in social science fields.

\section{REFERENCES}

1. Berry JW: Psychology of acculturation: In: Goldberger NR, ed. The Culture and Psychology Reader. New York: New York University Press; 1995:475-488

2. Foner N: West Indian migration to New York: An overview: In: Foner N, ed. Islands in the City. Los Angeles, CA: University of California Press; 2001:1-22

3. Foner N: Transnationalism then and now: New York immigrants today and at the turn of the twentieth century: In: Cordero-Guzman H, Smith R, Grosfoguel R, eds. Migration, Transnationalization \& Race in a Changing New York. Philadelphia, PA: Temple University Press; 2001:35-57

4. Portes A, Zhou M: Should immigrants assimilate? Public Interest 1994; 16:18-34

5. Waters M: Black Identities: Immigrant Dreams and American Realities. Cambridge, MA: Harvard University Press; 1999

6. Portes A, Rambaut R: Immigrant America: A Portrait. Berkeley, CA: University of California Press; 1990

7. Portes A: Immigration theory for a new century: Some problems and opportunities. Int Migration Rev 1997; 31(4):799825

8. Furnham A: The adjustment of sojourners: In: Kim Y, Gudykunst W, eds. Cross Cultural Adaptation. New York: Sage; 1987

9. Glick Schiller N, Basch L, Szanton Blanc C: From immigrant to transmigrant: Theorizing transnational migration. Anthropol Q 1995; 68(1):48-63

10. Goldring L: Blurring Borders: Constructing transnational community in the process of Mexico-US migration. Res Commun Sociol 1996; 6:69-104

11. Mahler S: Theoretical and empirical contributions toward a research agenda for transnationalism: In: Smith MP, Guarnizo LE, eds. Transnationalism From Below. New Brunswick, NJ: Transaction Press; 1998:64-100

12. Portes A, Gurarnizo LE, Landolt P: The study of transnationalism: Pitfalls and promise of an emergent research field. Ethn Rac Stud Rev 1999; 22(2):217-237

13. Smith M, Guarnizo L: Transnationalism From below. New Brunswick, NJ. Transaction Press; 1998

14. Foroun G, Glick Schiller N: The generation of identity: Redefining the second generation within a transnational social field: In: Cordero-Guzman H, Smith R, Grosfoguel R, eds. Migration, Transnationalization \& Race in a Changing New York. Philadelphia, PA: Temple University Press; 2001:35-57

15. Mahler S: Suburban transnational migrants: Long Island's Salvadorans: In: Cordero-Guzman H, Smith R, Grosfoguel R, eds. Migration, Transnationalization \& Race in a Chang- ing New York. Philadelphia, PA: Temple University Press; 2001:109-130

16. Graham P: Political incorporation and reincorporation: Simultaneity in the Dominican migrant experience: In: Cordero-Guzman H, Smith R, Grosfoguel R, eds. Migration, Transnationalization \& Race in a Changing New York. Philadelphia, PA: Temple University Press; 2001:87-108.

17. Lessinger J: Investing or going home? A transnational strategy among Indian immigrants in the United States: In: Glick Schiller N, Basch L, Blanc-Szanton C, eds. Towards a Transnational Perspective on Migration. New York: New York Academy of Sciences; 1992

18. Crawford-Brown C, Rattray J: Parent-child relationships in Caribbean families: In: Webb N, ed. Culturally Diverse Parent-Child and Family Relationships: A Guide for Social Workers and Other Practitioners. New York: Columbia University Press; 2001

19. Kasinitz P: Invisible no more? West Indian Americans in the social scientific imagination: In: Foner N, eds. Islands in the City. West Indian Migration to New York. New York: Columbia University Press; 2001:257-275

20. Henke H: Patterns of migration to the United States in the twentieth century: In: Henke H, ed. The West Indian Americans. Westport, CT: Greenwood Press; 2001

21. Foner N: New Immigrants in New York. New York: Columbia University Press; 1987

22. Pessar PR: Engendering migration studies. Am Behav Sci 1999; 42(4):577-600

23. Bobb V: Neither ignorance nor bliss: Race, racism and the West Indian immigrant experience: In: Cordero-Guzman H, Smith R, Grosfoguel R, eds. Migration, Transnationalization $\&$ Race in a Changing New York. Philadelphia, PA: Temple University Press; 2001:211-238

24. Rogers R: "Black like who?" Afro-Caribbean immigrants, African Americans, and the Politics of Group Identity: In: Foner N, ed. Islands in The City. Berkeley, CA: University of California press 2001:163-192

25. Ritsner M, Modai I, Ponizovsky A: The stress support patterns and psychological distress of immigrants. Stress Med 2000; 16:129-147

26. Allen E: West Indians: In Clinical guidelines in cross-cultural mental health. In: Comas-Diaz L, Griffith E, eds. New York: Wiley; 1987

27. Regis H: A theoretical framework for the study of the psychological sense of community of English-speaking Caribbean immigrants. J Black Psychol 1988; 15(1):5776

28. Sarason I, Levione H, Basham R, Sarason B: Assessing social support: The Social Support Questionnaire. J Pers Soc Psychol 1983; 44(1):127-139

29. Antonucci $\mathrm{T}$ : The negative effects of close social relationships. Fam Rel Interdisc J Appl Fam Stud 1998; 47(4, Special Issue):379-384

30. Nee V, Sanders J: Trust in ethnic ties: Social capital and immigrants: In: Cook K, eds. Trust in Society. Russell Sage Foundation Series on Trust, vol 2. New York: Russell Sage Foundation; 2001:374-392

31. Phinney JS: Ethnic Identity in adolescents and adults: Review of research. Psychol Bull 1990; 108:499-514

32. Phinney JS, Horenczy K, Liebkind K, Vedder P: Ethnic identity, immigration, and wellbeing: An interactional perspective. J Soc Iss 2001; 57(3):493-510

33. Gopaul-McNicol S, Brice-Baker J: Caribbean Americans: In: Friedman S, ed. Treatment of Anxiety Disorders Across Cultures. New York: Guilford Press; 1997

34. Phinney JS, Onwughalu M: Racial identity and perception of American ideals among African American and African students in the United States. Int J Intercult Rel 1996; 20(2):127140 
35. Gopaul-McNicol S: Working with West Indian Families. New York: Guilford Press; 1993

36. Waters M: Ethnic and racial identification of secondgeneration Black immigrants in New York City. Int Migration Rev 1994; 28, 4(108):795-820

37. Zimet G, Dahlem N, Zimet S, Farley G: The Multidimensional Scale of Perceived Social Support. J Pers Assess 1988; 52(1):30-41

38. Cohen S, Kamarck T, Mermelstein R: A global measure of perceived stress. J Health Soc Behav 1983; 24(4):385-396

39. Harrell, SP: The Racism and Life Experiences Scales. 1994. Unpublished Manuscript.
40. Diener E, Emmons R, Larson R, Griffin S: The satisfaction with life scale. J Pers Assess 1985; 49(1):71-75

41. Beck A, Ward C, Mendelson M, Mock L: An inventory for measuring depression. Archives of General Psychiatry 1961; 4:561-571

42. Beck A, Epstein N, Brown, G, Steer R: An inventory for measuring clinical anxiety: Psychometric Properties. Journal of Consulting and Clinical Psychology 1988; 56:893897

43. Ho C: Salt-Water Trinnies: Afro-Trinidadian Immigrant Networks and Non-Assimilation in Los Angels. New York: AMS Press; 1991 